\title{
Characteristics of Chemical Composition and Particle Size Distribution from Real Coal-fired Circulating Fluidised Bed (CFB) Boiler
}

\author{
Xin Du, Jianhui Wu*, Yingze Tian, Yufen Zhang, Baoshuang Liu, \\ Yinchang Feng*
}

The State Environmental Protection Key Laboratory of Urban Air Particulate Matter Pollution Prevention and Control, College of Environmental Science and Engineering, Nankai University, Tianjin 300071, China

\section{ABSTRACT}

The chemical component (element, ion, and carbonaceous aerosols) behaviour in particle size distributions (PSDs) was studied by determining the particulate matter (PM) emitted from the circulating fluidised-bed (CFB) combustion flue gas. Four CFB coal-fired boilers were employed in power plants. The actual particle mass percentages and PSDs were measured using an electrical low-pressure impactor (ELPI). Ion concentrations $\left(\mathrm{SO}_{4}{ }^{2-}, \mathrm{Cl}^{-}, \mathrm{NO}_{3}{ }^{-}, \mathrm{Na}^{+}, \mathrm{NH}_{4}{ }^{+}, \mathrm{Mg}^{2+}, \mathrm{K}^{+}\right.$and $\mathrm{Ca}^{2+}$ ) were determined by ion chromatography (IC), elements ( $\mathrm{Al}, \mathrm{Ca}, \mathrm{Cr}, \mathrm{Cu}, \mathrm{Fe}, \mathrm{K}, \mathrm{Mg}, \mathrm{Na}, \mathrm{Ni}, \mathrm{Pb}, \mathrm{S}, \mathrm{Si}$, $\mathrm{Ti}$ and $\mathrm{Zn}$ ) were determined by inductively coupled plasma-mass spectrometry (ICP-AES), and the carbonaceous content $(\mathrm{OC} 1, \mathrm{OC2}, \mathrm{OC} 3, \mathrm{OC} 4, \mathrm{EC} 1, \mathrm{EC} 2$ and EC3) was measured by thermal optical analysis. Significant differences were observed in the four boilers for PSD. Chemical species in particulate matter mainly concentrated in sizes $0.1-2.5 \mu \mathrm{m}$ in aerodynamic diameter. In this work, the mass percentage of $\mathrm{Ca}, \mathrm{Ca}^{2+}, \mathrm{SO}_{4}{ }^{2-}, \mathrm{NH}_{4}{ }^{+}$and $\mathrm{OC}$ were significantly high in different particle size regions. The mass concentrations of elements, ions, and carbonaceous aerosols in various sizes displayed trimodal or bimodal distributions; however, the peaks of mass concentrations of chemical species in different particle sizes varied greatly. Furthermore, the size distribution of chemical species was influenced by the pollution control device employed, and the same chemical species showed a marked difference among coal-fired boiler equipped with different pollution control devices. In addition, it was observed that the ratio of OC to EC was related to dust-cleaning method.

Received: August 28, 2020

Revised: December 11, 2020

Accepted: January 6, 2021

\footnotetext{
${ }^{*}$ Corresponding Authors: Jianhui Wu envwujh@nankai.edu.cn Yinchang Feng

fengyc@nankai.edu.cn
}

\section{Publisher:}

Taiwan Association for Aerosol Research

ISSN: $1680-8584$ print

ISSN: 2071-1409 online

\section{Copyright: The Author's} institution. This is an open access article distributed under the terms of the Creative Commons Attribution License (CC BY 4.0), which permits unrestricted use, distribution, and reproduction in any medium, provided the original author and source are cited.
Keywords: Coal-fired Circulating Fluidised Bed (CFB), Particulate matter, Particle size distribution, Chemical components

\section{INTRODUCTION}

Atmospheric particulate matter (PM) is one of the principal pollutants of urban air in China. PM emissions from coal-fired boilers are an important source of atmospheric pollution (Xu et al., 2017; Yue et al., 2020). The size distribution of particulate matter (PM) is a significant PM attribute and has previously been investigated (Linak et al., 2002; Zhang et al., 2012). It is important not only to understand its effects on human health, visibility impairment, climate change, and transformation processes during atmospheric transport, but also to contribute to the source apportionment researches (Racherla and Adams, 2006; Yang et al., 2007; Pan et al., 2013; Bari and Kindzierski, 2016; Zhang et al., 2016; Jia et al., 2018). Emissions from boilers have aroused great concern, as they not only produce gaseous pollutants, for instance, $\mathrm{CO}, \mathrm{CO}_{2}, \mathrm{NO}_{x}$ and $\mathrm{SO}_{2}$ (Dios et al., 2013; Hussain and Luo, 2019), but also emit PM. Moreover, the characteristics of PM are different because of combustion processes transformation, such as different types of boilers, different coal burning conditions and pollution control devices (Yi et al., 2008; Ma et al., 2017; 
Wu et al., 2018; Wang et al., 2019). As is well-known, coal is the major energy for boiler combustion, and it is usually used in different industrial applications such as electricity, industrial heat, and residential heating with characteristics of coal-fired emission sources (Li et al., 2018). China accounts for approximately one-third of the world's coal combustion every year (Ma et al., 2016). Therefore, PM emitted from coal-burning boilers has caused considerable concern over the regional air pollution effects.

Chemical components (elements, ions and carbonaceous aerosols) from coal-fired boilers are released into the atmosphere as particle emissions and toxic elements have been found to be enriched in ultrafine and fine particles (Yoo et al., 2005). Relevant studies have focused on the elements from coal-fired boilers (Gao et al., 2016; Huang et al., 2017; Lanzerstorfer, 2018). Watersoluble ions, especially, $\mathrm{SO}_{4}{ }^{2-}, \mathrm{Ca}^{2+}$ and $\mathrm{NH}_{4}{ }^{+}$are significant in PM (Saarnio et al., 2014); however, water-soluble ion emissions are affected by the chemicals used in the desulphurisation and denitrification processes (Saarnio et al., 2014; Wu et al., 2018). Carbonaceous aerosols, including organic carbon (OC) and elemental carbon (EC), are ubiquitous species in the atmosphere. OC is derived from the complete combustion of coal and secondary transformation (Saud et al., 2013; Cornette et al., 2020), whereas EC is mainly produced by incomplete combustion of coal (Masiello, 2004; Peng et al., 2018). The OC and EC from coal-fired coal has been reported (Ma et al., 2016). The conclusions from this study suggest that grate boiler emissions had higher levels of OC and EC, with emission rates about 16 and 10 times higher than those of the pulverised combustion boilers and circulating fluidised bed (CFB), respectively. However, the chemical composition of coal (elements, ions, and carbonaceous aerosols) has rarely been reported for the size distribution of particulate matter (PM), and their chemical feature have rarely been reported; previous studies have mainly focused on the chemical and physical properties of coarse particle emissions.

In this study, we characterise the PM at the outlet of particulate emission control devices (PECDs) for four coal-fired power plants (CFPPs) with CFB boilers, a new technology with the ability to reduce pollutant emissions (Li et al., 2013). We describe the emission characteristics of eleven particle size intervals with a size range of 0.013-10.5 $\mu \mathrm{m}$. The focus of the study was on particles that are emitted to the atmosphere from CFPP after different pollution cleaning devices. Therefore, based on different pollution control devices and and flue gas temperatures, the characteristics of the particle chemical composition (element, ion and carbonaceous aerosols) in different particle sizes were studied. The actual particle mass percent and PSDs were picked up from electrical low-pressure impactor (ELPI) measurements. Based on the analysis method, the particle chemical composition (element, ion and carbonaceous aerosols) was determined.

\section{METHODS}

\subsection{Selection of Sampling Points}

Particulate sampling points were selected at the rectangular flue after the flue gas desulphurisation system (FGD). Four CFPPs were equipped with CFB units, which is one of the most widely used industrial boilers in China. The CFB boilers are widely employed in China and represent advanced combustion technologies. Table 1 lists the boiler load, equipment for pollution treatment, flue gas temperature $(T)$ and flue gas relative humidity $(\mathrm{RH})$ for the four boiler units, which are mainly utilised for power generation and supply resident heating. To reduce environmental pollution from thermal power plants, the air pollution removal technology is similar to other technologies. In this work, dust removal techniques are introduced: bag filter, electrostatic precipitators (ESP) and electrostatic bags (ESB). Desulphurisation technologies are employed with semi-dry flue gas desulphurisation (SDFGD), dry flue gas desulphurisation (DFGD), and ammonia desulphurisation (AD).

Table 1. Units, temperature, and particle control devices.

\begin{tabular}{lllllll}
\hline Boiler code & Load $(\mathrm{t})$ & $\mathrm{RH}(\%)$ & $\mathrm{T}\left({ }^{\circ} \mathrm{C}\right)$ & Dust remover & Desulphurisation & Denitrification \\
\hline CFB1 & 1210 & 9.7 & 74 & bag filter & SDFGD & SCR \\
CFB2 & 150 & 6 & 130 & ESP & DFGD & SNCR \\
CFB3 & 480 & 11 & 50 & Electric bag & AD & SNCR \\
CFB4 & 470 & 10 & 42.2 & Electric bag & DFGD & No control \\
\hline
\end{tabular}




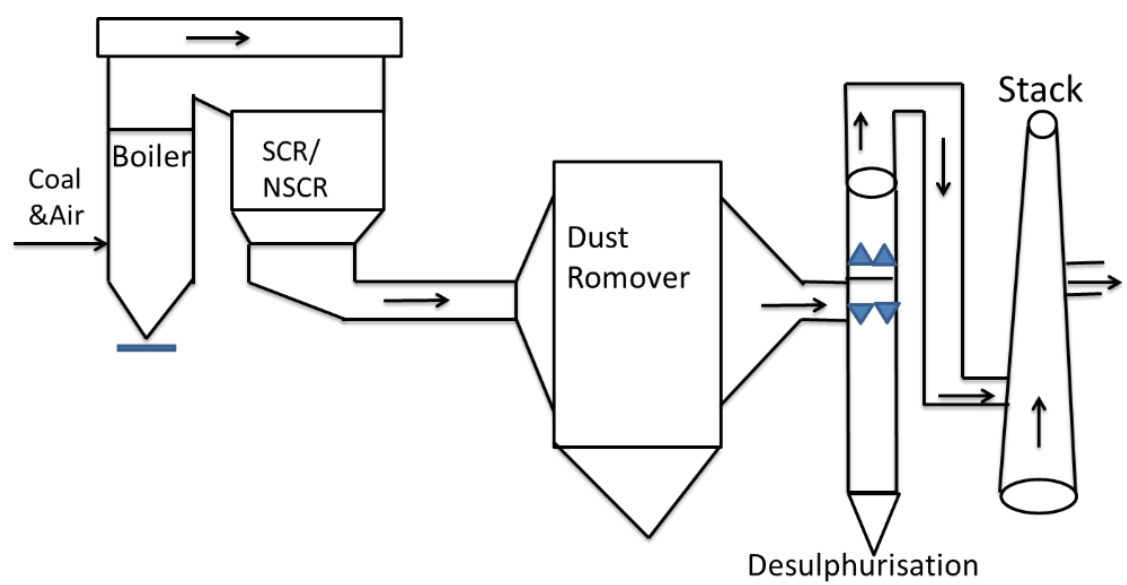

Fig. 1. Schematic configuration of APCDs and sampling site.

Denitrification methods include selective catalytic reduction (SCR) and selective non-catalytic reduction (SNCR). During the test, all the boilers and the air pollution control devices (APCDs) were operated under normal conditions; in addition, the fuel properties and combustion conditions were stable. Fig. 1 illustrates the schematic configuration of APCDs and sampling site.

\subsection{Sampling Methods}

The sampling system consisted of a pump, $\mathrm{ELPI}^{+}$, pre-heat tube, isokinetic sampler probe, precut cyclone (cut-off diameter of $10.23 \mu \mathrm{m}$ ), and one-stage dilution system. Clean and dry pressurised air was used as the dilution gas at a dilution ratio of approximately 8 in this work. An ELPI (ELPI+, Dekati Ltd., $101 \mathrm{pm}$ ) was applied to measure the particle size distributions of PM, which were divided into eleven size fractions and ranged from 0.006 to $10.23 \mu \mathrm{m}$ in diameter, while particles with an aerodynamic diameter larger than $10.23 \mu \mathrm{m}$ were removed by the pre-impactor (Marjamki et al., 2000). When flue gas emission flowed into a pre-heat tube, a diluter (Finland, Dekati Ltd.), cyclone separator, and ELPI+ in turn, particulate matter was collected in the quartz membrane and Teflon membrane with a diameter of $25 \mathrm{~mm}$ by the ELPI impactor. During the sampling process, the stack flue gas was heated by the thermal insulation material. Therefore, the sample system is a real-time size analyser that facilitates study of PM directly emitted to the atmospheric environment.

\subsection{Analytical Methods}

In this experiment, the Teflon filters and quartz membrane were weighed to obtain mass concentrations of PM using an analytical balance, accurate to $0.01 \mathrm{mg}$ (XPE105, Switzerland Mettler Toledo). Water-soluble ions ( $\mathrm{Na}^{+}, \mathrm{NH}_{4}{ }^{+}, \mathrm{K}^{+}, \mathrm{Mg}^{2+}, \mathrm{Ca}^{2+}, \mathrm{F}^{-}, \mathrm{Cl}^{-}, \mathrm{NO}_{3}{ }^{-}, \mathrm{NO}_{2}^{-}$and $\mathrm{SO}_{4}{ }^{2-}$ ) and elements ( $\mathrm{Si}, \mathrm{Al}, \mathrm{V}, \mathrm{Ti}, \mathrm{Cr}, \mathrm{Mn}, \mathrm{Fe}, \mathrm{Cu}, \mathrm{Zn}, \mathrm{As}, \mathrm{Se}, \mathrm{Cd}, \mathrm{Sb}, \mathrm{Ba}, \mathrm{Ti}$ and $\mathrm{Pb}$ ) were collected using Teflon filters and a quartz membrane with a $25 \mathrm{~mm}$ diameter, respectively. Particulate filters were cut into thin strips and then immersed in an ultrasonic bath (GT-2120QTS, China) for 10 min in mixed acid solutions ( $8 \mathrm{~mL} \mathrm{HNO}_{3}, 2 \mathrm{~mL} \mathrm{HCl}$ and $1 \mathrm{~mL} \mathrm{H} \mathrm{O}_{2}$ ), and ions and elements were extracted in a microwave digestion system (CEM, USA) for $45 \mathrm{~min}$. The solution from Teflon filters was then drawn into a syringe, filtered, and injected into an ion chromatograph system (DIONEX ICS-900, Thermo Fisher Scientific Inc., USA) at a flow rate of $1.2 \mathrm{~mL} \mathrm{~min}^{-1}$. The solution from the quartz membrane was analysed by inductively coupled plasma-mass spectrometry and atomic emission spectroscopy (ICP-AES) (ICP7000 Series-AES, Thermo Fisher Scientific Inc., USA).

$O C$ and $E C$ were sampled on the quartz membrane and then measured with the DRI model 2001A Thermal/Optical Carbon analyser (Thermo Fisher Scientific Inc., USA), which is based on the IMPROVE_A thermal/optical reflectance (TOR) protocol (Chow et al., 2001). In a helium atmosphere, while the quartz filter was warmed at $120^{\circ} \mathrm{C}, 250^{\circ} \mathrm{C}, 450^{\circ} \mathrm{C}$ and $550^{\circ} \mathrm{C}$, it produced $\mathrm{OC} 1, \mathrm{OC2}, \mathrm{OC} 3$ and OC4, respectively. With an increase in temperature, EC1, EC2 and EC3 were determined in a $2 \%$ oxygen $/ 98 \%$ helium atmosphere at $580^{\circ} \mathrm{C}, 740^{\circ} \mathrm{C}$ and $840^{\circ} \mathrm{C}$, respectively. The pyrolyzed carbon fraction (POC) was measured when the reflected laser light achieved its original 
intensity after oxygen was added to the combustion atmosphere. Therefore, $\mathrm{OC}$ is defined as $\mathrm{OC} 1$ $+\mathrm{OC} 2+\mathrm{OC} 3+\mathrm{OC} 4+\mathrm{POC}$, and EC is defined as EC1 + EC2 + EC3 - POC.

\subsection{Quality Control}

Filters were conditioned at a constant $\mathrm{T}\left(20 \pm 5^{\circ} \mathrm{C}\right)$ and $\mathrm{RH}(40 \pm 2 \%)$ for two days before and after weighting. After sample collection, filters were placed in the filter boxes at once, and then stored in a refrigerator at $2^{\circ} \mathrm{C}$ until chemical analysis. Each filter was weighed at least three times before and after sampling, and the particle mass was determined by subtracting the average of the pre-sampling weights from the average of the post-sampling weights. The quartz filters were baked at $900^{\circ} \mathrm{C}$ for $4 \mathrm{~h}$ before sampling. The sampling impactor was washed with deionised water before sampling. Anion/cation calibration solutions were used for calibration of the ICs on the AIM for at least one month. The minimum detection limits (MDLs) were: $0.2 \mu \mathrm{g} \mathrm{m}^{-3}\left(\mathrm{Cl}^{-}\right)$, $0.2 \mu \mathrm{g} \mathrm{m}^{-3}\left(\mathrm{~F}^{-}\right), 0.2 \mu \mathrm{g} \mathrm{m}^{-3}\left(\mathrm{NO}_{3}{ }^{-}\right), 0.2 \mu \mathrm{g} \mathrm{m}^{-3}\left(\mathrm{NO}_{2}{ }^{-}\right), 0.3 \mu \mathrm{g} \mathrm{m}^{-3}\left(\mathrm{SO}_{4}{ }^{2-}\right), 1.8 \mu \mathrm{g} \mathrm{m}^{-3}\left(\mathrm{NH}_{4}{ }^{+}\right), 2.3 \mu \mathrm{g} \mathrm{m}{ }^{-3}$ $\left(\mathrm{Ca}^{2+}\right), 0.8 \mu \mathrm{g} \mathrm{m}^{-3}\left(\mathrm{Mg}^{2+}\right), 0.5 \mu \mathrm{g} \mathrm{m}^{-3}\left(\mathrm{~K}^{+}\right)$and $0.6 \mu \mathrm{g} \mathrm{m}^{-3}\left(\mathrm{Na}^{+}\right)$. Calibration curves of the measured elements were obtained, and the correlation coefficient values were all above 0.99 . The minimum detection limits (MDLs) were: Al (16.4 ppb), Ca (243 ppb), Cr (6.20 ppb), Cu (1.47 ppb), Fe (32 ppb), K (17.7 ppb), Mg (7.4 ppb), Na (51 ppb), Pb (5.5 ppb), S (47 ppb), Si (23.2 ppb), Ti (3.16 ppb), Zn (23.1 ppb), Ni (6.9 ppb). The detection limits for OC and EC were 0.40 and $0.05 \mu \mathrm{g} \mathrm{cm}^{-2}$, respectively. The flow calibration, gas tightness test, blank filter test, and standard sample calibration were all conducted for QA/QC.

\section{RESULTS AND DISCUSSION}

\subsection{Characteristics of Chemical Components in Size-segregated Particles}

\subsubsection{Element}

Particle size distributions of element mass percent are shown in Fig. 2, fourteen elements in $\mathrm{PM}_{2.5}$ were listed and studied from four CFB coal-fired units. Among all the elements, $\mathrm{Ca}, \mathrm{Al}$, and $\mathrm{S}$, were main component in $\mathrm{PM}_{2.5}$. However, the average mass percent of $\mathrm{Ca}$ was obviously higher than that of the other elements and accounted for a range from $10 \%$ to $28 \%$ in the four CFBs. In the power plant, $\mathrm{Ca}$ not only stems from coal combustion, but is also closely linked to desulphurisation methods. Ca from the dissolution of limestone is the main constituent of slurry, and the entrainment of slurry contributes significantly to $\mathrm{PM}_{2.5}$ emissions (Li et al., 2017). In our experiment, desulphurisation process with $\mathrm{SO}_{2}$ reacting with the limestone slurry can reduce $\mathrm{SO}_{2}$ emissions from the flue gas. Therefore, a large amount of water-based calcium was taken into the flue gas. The size distribution of element abundance in flue gas for coal combustion (Fig. 2) showed that the elements were distributed across almost all particle size classes with the peaks in different size fraction regions. $\mathrm{Al}, \mathrm{Cr}$, Fe and $\mathrm{K}$ peaked at $0.37-0.61 \mu \mathrm{m}, \mathrm{Na}$ peaked at 0.37-0.95 $\mu \mathrm{m}$ and 6.89-10.23 $\mu \mathrm{m}$. S primarily focused in ultrafine particles with a size range of $0.13-0.61 \mu \mathrm{m}$, the mass percentages of $\mathrm{Cu}, \mathrm{Pb}$ and $\mathrm{Ni}$ were so low that they were found evenly in all size ranges. The mass percentage of Ca was remarkably high in all size ranges, and it seemed to be separated evenly between the fine and coarse fractions, as were Fe and S. But our results were different from the one reported by Gao et al. (2007) who measured elemental size distribution of $\mathrm{PM}_{10}$ at outlet of dust cleaning equipment in coal fired boiler and found that the size distribution of $\mathrm{Ca}, \mathrm{S}$ and $\mathrm{Fe}$ is obvious bimodal with the peak at $0.1 \mu \mathrm{m}$ and $2.5 \mu \mathrm{m}$. Al and Si were the most prevalent components of coal combustion (Ninomiya et al., 2004), both had the same particle size distribution trend and peaked at size ranges of $0.37-0.61 \mu \mathrm{m}$ and $1.52-4.10 \mu \mathrm{m}$.

\subsubsection{Water-soluble ions}

For ionic profiles, the size distribution of ionic mass percentage is given in Fig. 3 , the determination results showed that $\mathrm{SO}_{4}{ }^{2-}, \mathrm{Na}^{+}, \mathrm{NH}_{4}{ }^{+}$and $\mathrm{Ca}^{2+}$ were significant anions from $\mathrm{PM}_{2.5}$ emissions in CFBs. Furthermore, in this work, the average mass percent of $\mathrm{K}^{+}$only accounted for $2.1 \%$ of the $\mathrm{PM}_{2.5}$, lower than $11.1 \%$ as reported by Wang et al, who selected and tested coalfired boiler without air pollution control devices. The result indicated that dust-removing equipment may influenced $\mathrm{K}^{+}$remove performance. $\mathrm{Ca}^{2+}$ was at a relatively high level and it was 

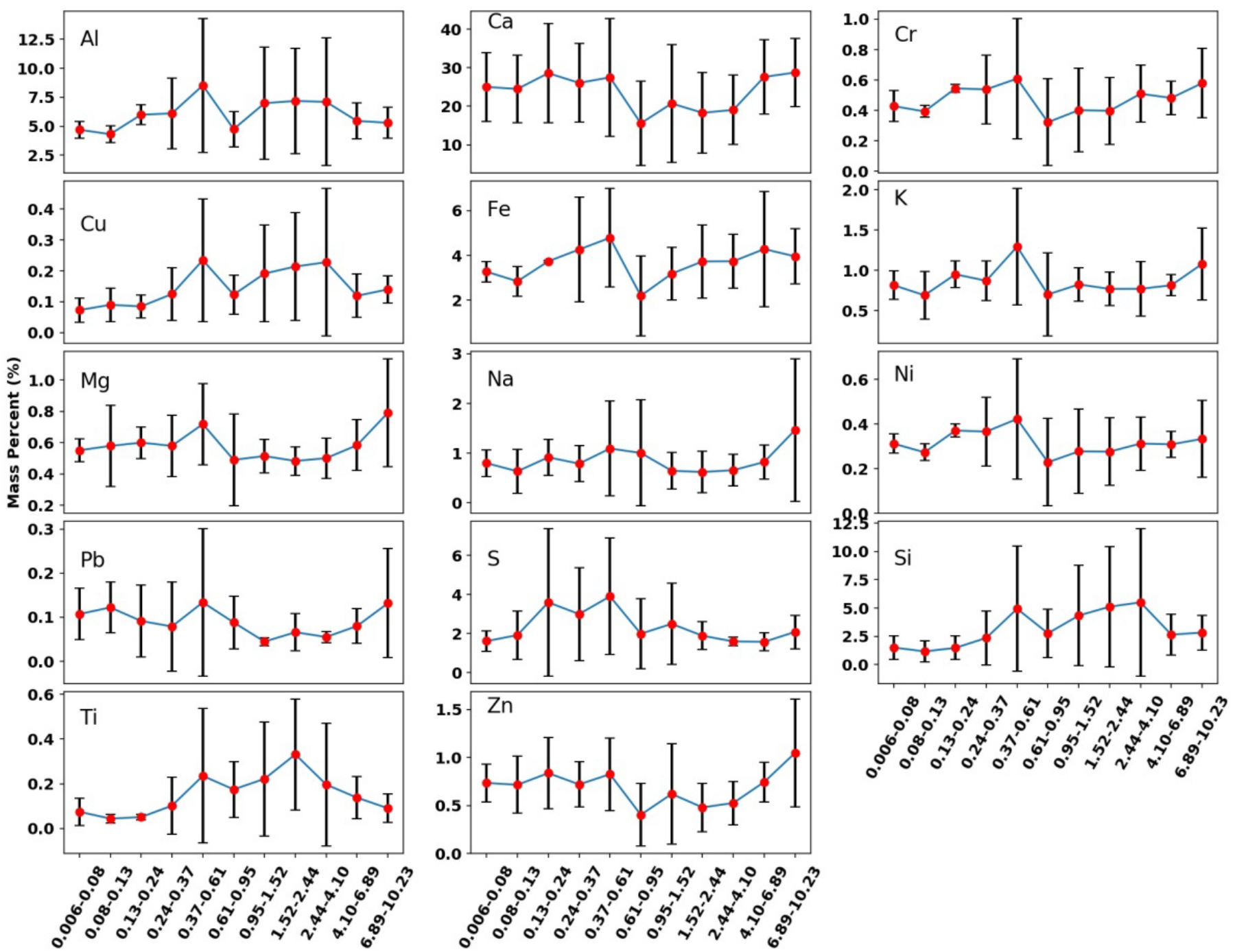

Fig. 2. Percentage of elements mass in each particle-size bin (the error bar represents the standard deviation of different elements).

confirmed that the entrainment of recirculated slurry contributes significantly to the $\mathrm{PM}_{2.5}$ emissions because $\mathrm{Ca}^{2+}$ from limestone dissolution is the main slurry ingredient, and limestone may be mixed with some impurities, such as $\mathrm{Mg}^{2+}$ (Saarnio et al., 2014). In this work, $\mathrm{SO}_{4}{ }^{2-}$ was higher than $\mathrm{NH}_{4}{ }^{+}$in terms of mass concentration, and both of them were found to be enriched in PM emitted from CFPP. The SCR/ SNCR installation may have led to an increase in $\mathrm{NH}_{3}$ content in the flue gas, and some $\mathrm{NH}_{3}$ was converted into $\mathrm{NH}_{4}{ }^{+}$during the desulphurisation process before being emitted into the atmosphere. So it increased the $\mathrm{NH}_{4}{ }^{+}$emission. The increase $\mathrm{SO}_{4}{ }^{2-}$ concentration was due to $\mathrm{SO}_{2}$ to $\mathrm{SO}_{4}{ }^{2-}$ conversion occurred in the desulphurisation process prior to atmospheric emission. Simultaneously, the SCR/SNCR coupled with the desulphurisation system also tended to promote the conversion of $\mathrm{NO}_{4}$ to $\mathrm{NO}_{3}{ }^{-}$, leading increased $\mathrm{NO}_{3}{ }^{-}$emissions as well. $\mathrm{Cl}^{-}$was relatively high, and was primarily released as $\mathrm{HCl}$ from feed coal fires (Senior et al., 2000). The water-soluble ions in the eleven size fractions are shown in Fig. 3. In general, the abundances of most water-soluble ions were distributed in all particle size classes with peaks appearing in sizes less than $1 \mu \mathrm{m}$. The mass percentage of $\mathrm{Mg}^{2+}$ was very low in all size ranges and was quite even in all size ranges. $\mathrm{SO}_{4}{ }^{2-}$ and $\mathrm{NH}_{4}{ }^{+}$presented similar trends at less than $2.5 \mu \mathrm{m}$ with the peak at 0.37-0.61 $\mu \mathrm{m}$, whereas $\mathrm{SO}_{4}{ }^{2-}$ showed another peak at 2.44-4.10 $\mu \mathrm{m}$. $\mathrm{Cl}^{-}$and $\mathrm{NO}_{3}{ }^{-}$had similar size distributions, with peaks of $0.13-0.24,2.44-4.10$ and $6.89-10.23$. $\mathrm{Na}^{+}$ presented two peaks at a range of $0.37-0.61$ and $1.52-1.44 . \mathrm{Ca}^{2+}$ was mainly concentrated in sizes of $0.006-0.08$ and $0.61-0.95$. 

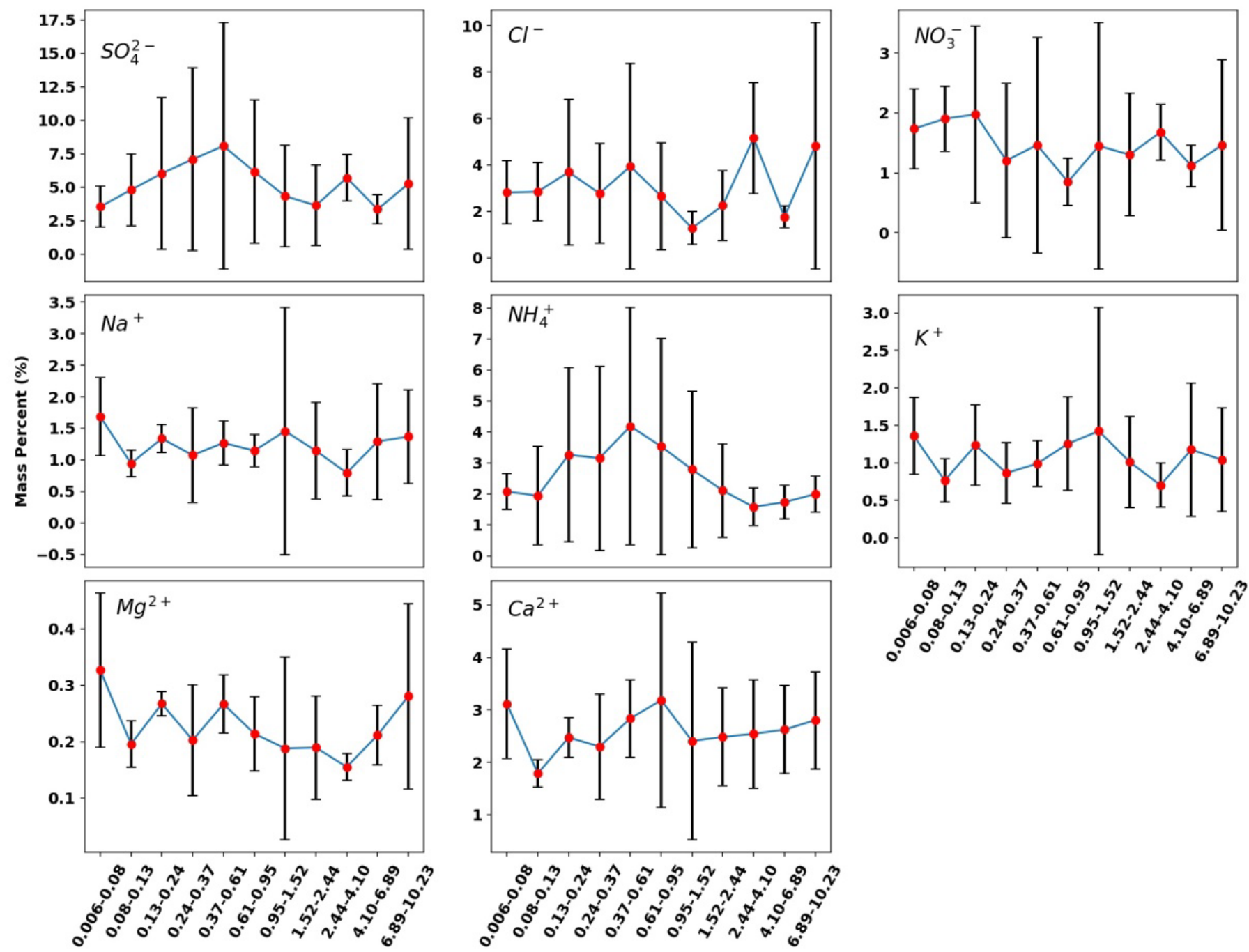

Fig. 3. Percentage of ionic mass in each particle-size bin (the error bar represents the standard deviation of different ions).

\subsubsection{OC, EC, and carbon fraction characteristics}

Carbonaceous species included OC and EC. It was found that the abundance of EC was lower than that of $O C$ in the size range of five units, similar to the results reported by Ma et al. (2016) Carbonaceous aerosols are subdivided into different fractions, which are usually employed as tracers of coal-burning sources (Han et al., 2010). The carbon fractions (OC1, OC2, OC3, OC4, EC1, EC2 and EC3) can be recognized by the decomposition temperatures. As shown in Fig. 4, the size distribution of mass percentage of $O C$ and EC in CFB displayed a double-peak distribution consisting of sub-micrometre modes with peaks at $\mathrm{PM}_{0.13-0.24}$ and a coarse peak at $\mathrm{PM}_{2.44-4.10}$. The mass percentage of OC1 from the CFB stack revealed a parallel size distribution with OC and EC, and the size displayed two peaks near 0.37 and $6.89 \mu \mathrm{m}$. The content of OC2 and OC3 in PM0.130.24 was higher than that in other particle sizes. The mass percentage of OC4 revealed a trimodal distribution with peaks near $0.24,0.95$ and $4.10 \mu \mathrm{m}$, respectively. The abundance of EC1 and EC2 in $\mathrm{PM}_{0.13-0.24}$ is at the highest level among size distribution.

\subsubsection{Variation of particle size distributions (PSDs) across different pollution control devices}

$\mathrm{PM}_{2.5}$ contributed to $70 \%$ of the $\mathrm{PM}_{10}$ mass, which is higher than average mass percent (34\%) of $\mathrm{PM}_{10}$ at WFGD outlet reported by Wu et al, it may be thought that a desulfurization technology can influence PM (Álvarez-Ayuso et al., 2006). The mass percentages of ionic species from smokestack flue gas for the four tested CFB power plants are presented in Fig. 5. It is noted that there is a 

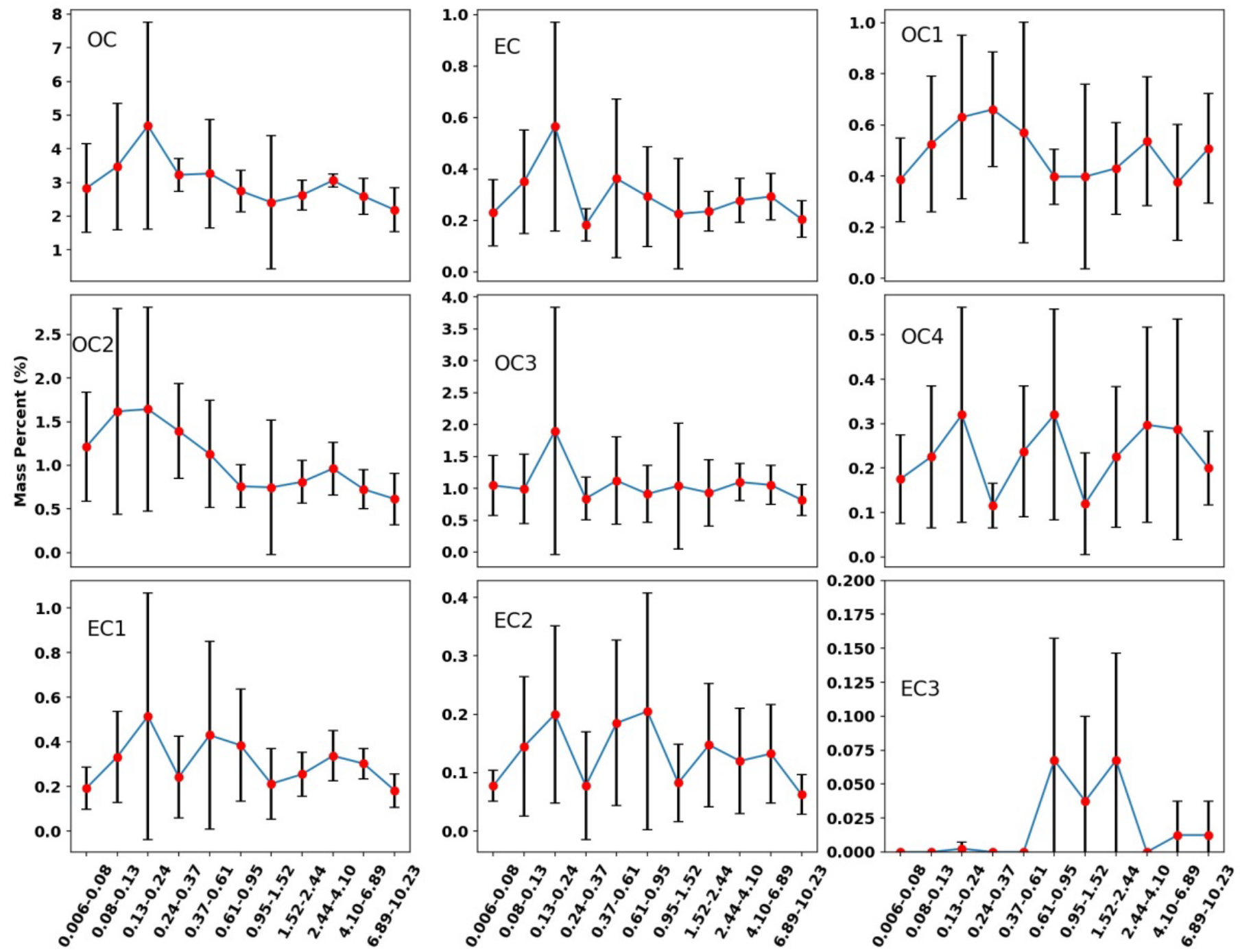

Fig. 4. Percentage of OC, EC, OC and EC fragments in different particle-size bins (the error bar represents the standard deviation of different carbons).

difference in the size distribution of ionic species in different CFBs. In this work, the content of $\mathrm{NH}_{4}{ }^{+}$ in different particulate diameters was significant enrichment and showed unimodal distribution in CFB3. The contents of $\mathrm{Na}^{+}$and $\mathrm{K}^{+}$made small differences, except for $\mathrm{PM}_{0.95-1.52}$ and $\mathrm{PM}_{4.1-10}$ in the four CFBs. The content of $\mathrm{Cl}^{-}$had two or three peaks in different CFBs, such as CFB1 with PM0.13-0.24 and $\mathrm{PM}_{6.89-10.23}, \mathrm{CFB} 3$ with $\mathrm{PM}_{0.37-0.61}$ and $\mathrm{PM}_{2.44-4.10}$, and CFB4 with $\mathrm{PM}_{0.37-0.61}, \mathrm{PM}_{2.44-4.10}$ and $\mathrm{PM}_{6.89-10.23}$. The content of $\mathrm{SO}_{4}{ }^{2-}$ displayed a single peak in $\mathrm{PM}_{0.37-0.61}$ in CFB3; However, all ions of $\mathrm{PM}_{0.13-0.61}$ had a high abundance in CFB4. In CFB1, the $\mathrm{SO}_{4}{ }^{2-}$ of PM0.95-1.52 and $\mathrm{PM}_{6.89-10.23}$ was obviously increased. In $\mathrm{CFB} 1$ and $\mathrm{CFB} 4, \mathrm{NO}_{3}{ }^{-}$showed trends similar to those of $\mathrm{SO}_{4}{ }^{2-}$. It emitted more $\mathrm{NH}_{4}{ }^{+}$in CFB3 because of the plant equipped ESP coupled with AD and SNCR (Sereika et al., 2017). $A D$ removed $\mathrm{SO}_{2}$, replacing $D F G D$ in $C F B 1, C F B 2$, and $C F B 4$; however, $A D$ process can release more new $\mathrm{NH}_{4}{ }^{+}$to the atmosphere, and DFGD system can produce more $\mathrm{Ca}^{2+}$ or $\mathrm{Ca}$. In addition, SCR/SNCR has been used to remove nitrogen oxides and it also forms new $\mathrm{NH}_{4}{ }^{+}$ (Ramachandran et al., 2000; Arfaoui et al., 2009). Ninomiya et al. (2004) showed that coal particle size can affect PM emission and its chemical species in different size fractions. Additionally, $\mathrm{SO}_{4}{ }^{2-}$ had a good correlation with $\mathrm{NH}_{4}{ }^{+}(0.65)$ in CFB3 equipped with ammonia absorption methods for fume desulphurisation, so the main components in the particle samples might be $\left(\mathrm{NH}_{4}\right)_{2} \mathrm{SO}_{4}$. $\mathrm{Ca}^{2+}$ and $\mathrm{SO}_{4}{ }^{2-}$ correlated well in different-sized particles (CFB1, CFB2 and CFB4 with 0.59, 0.78 and 0.69 , respectively). From this result, it may be presumed that $\mathrm{CaSO}_{4}$ is the main ingredient in the particle samples, and these compounds were formed in the particle phase principally during 

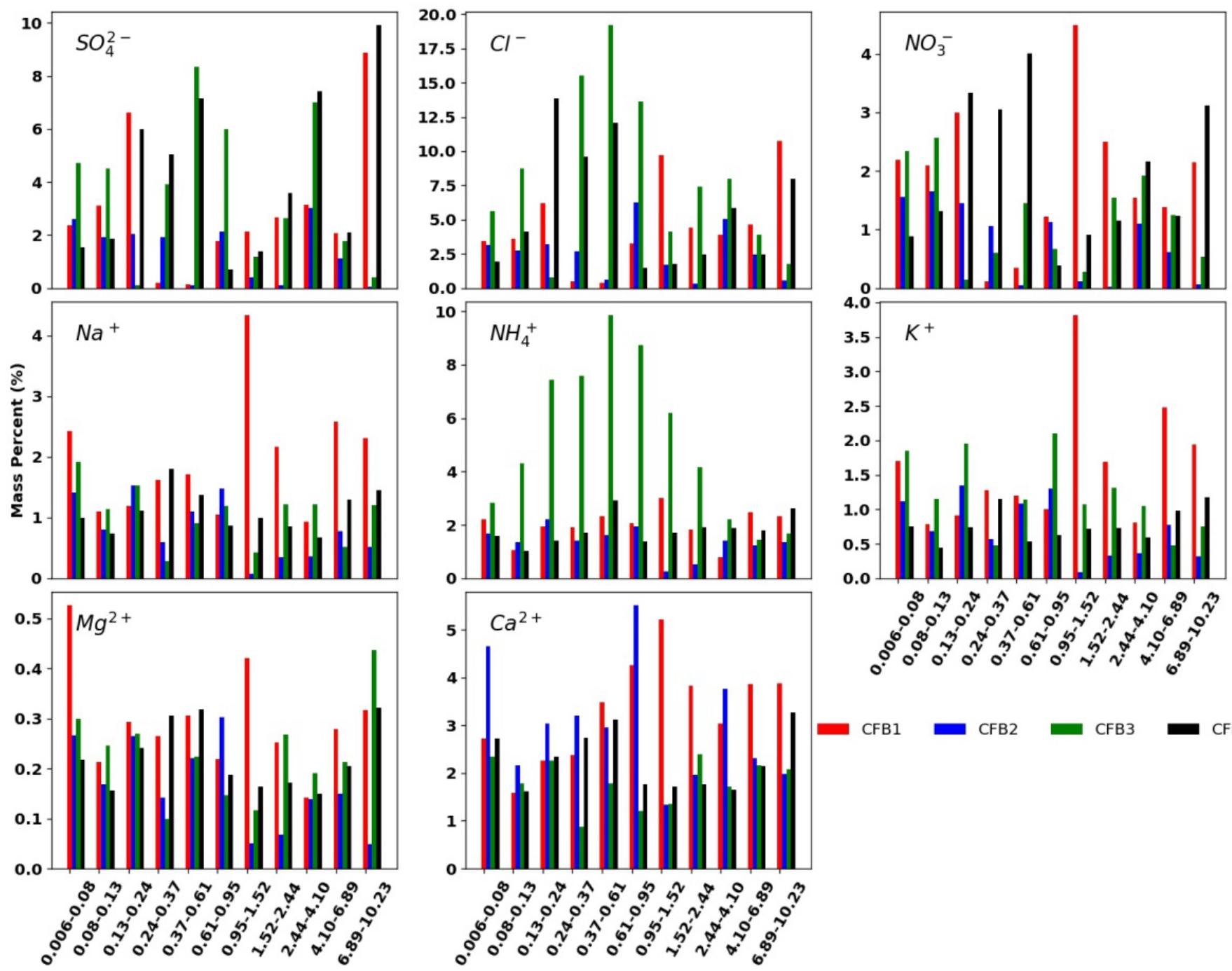

Fig. 5. Ion distributions with different particle-sizes bins from four CFBs (\%).

the flue gas desulphurisation process. It was regarded that APCDs can affected the abundance of chemical species in coal-fired boiler. (Meij and Winkel, 2004; Yi et al., 2008).

The OC and EC mass percentages in different size fractions $(0.006-10.23 \mu \mathrm{m})$ for the four units (measured with ELPI) are illustrated in Fig. 6. OC was observed to vary in the same particle size range from different CFB boilers. There are at least two obvious peaks that were observed for mass distribution of $O C$ and $E C$ in different sizes from four CFB units. The mass distribution of $O C$ and EC from CFB2 equipped with ESP were different from those in other boilers. OC and EC revealed analogical size distribution from CFB1 equipped with bag dust cleaning, with the size showing one peak approaching $0.13 \mu \mathrm{m}$. However, the mass percentages of OC and EC from the four CFB stacks made a large difference in size distribution. The mass distribution of OC and EC from the CFB2 was more complex than those in the other CFBs. In CFB2, four conspicuous peaks for mass distribution of $O C$ and EC were observed, while in other CFBs they displayed a bimodal distribution. Linak et al. (2002) found that pulverised coal fly particle has a trimodal PSD with sub-micrometre region, fine region, and super-micrometre region. In addition, there were differences about the average mass percentage of OC and EC for different CFB boilers. Approximately 3.5\%, 1.9\%, 6.3\% and 1.8\% of the OC were emitted from CFB1, CFB2, CFB3 and CFB4, respectively. EC displaying an analogical change based on the four sampled boilers, and approximately $0.49 \%, 0.17 \%, 0.48 \%$ and $0.20 \%$ in the $\mathrm{PM}_{2.5}$ emitted from the four CFB units. The four boilers used the same combustion method, but CFB3 and CFB4 employed electric-bag precipitator, whose dusting ways are from CFB1 and CFB2. So dust removal technology might affect the mass distribution of $O C$ and $E C$ in different sizes. 

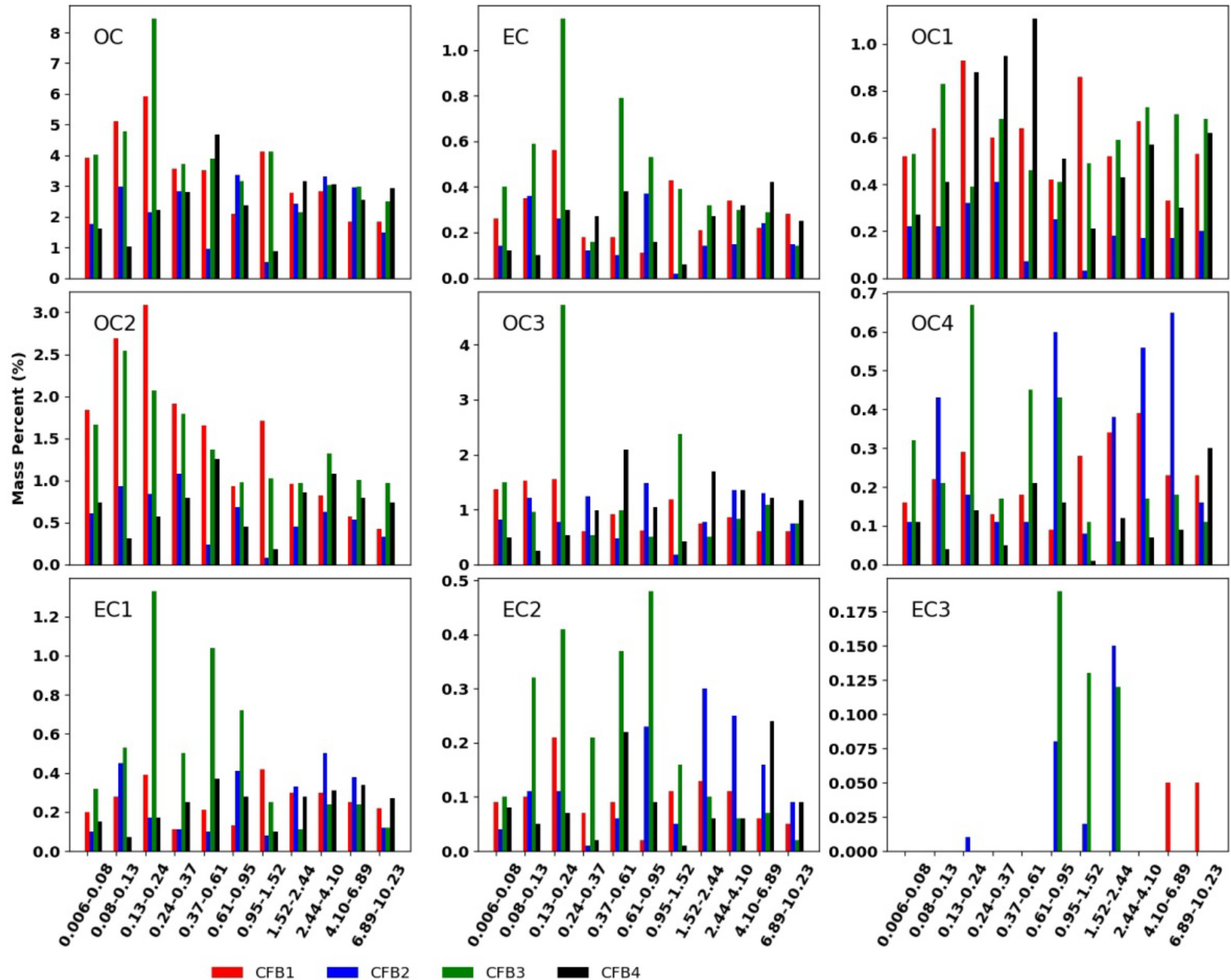

Fig. 6. Particle size distribution for OC, EC, OC and EC fragments in different CFBs.

The evaporation from OC1 and OC2, considered as volatile organic compounds and semi volatile organic compounds, respectively, occurred below $250^{\circ} \mathrm{C}$ (Duan et al., 2012). Therefore, OC1 and OC2 were stable at relatively low temperatures. In our work, CFB3 and CFB4 presented similar combustion methods; furthermore, CFB3 and CFB4 were equipped with the same electric bag. In CFB3 and CFB4, the mass distribution of the organic carbon fraction (OC1, OC2, OC3 and OC4) were remarkable distinction. In CFB3 (Fig. 6), the OC3 displayed an obvious double peaks consisting of one sub-micrometre region with peaks at $\mathrm{PM}_{0.13-0.24}$ and a fine peak at $\mathrm{PM}_{0.95-1.52 \text {, }}$ and $\mathrm{OC2}$ had one peak with $\mathrm{PM}_{0.08-0.13}$ at a gas temperature of $50^{\circ} \mathrm{C}$. In CFB2 (Fig. 6), the OC1, OC2, OC3 and OC4 had similar size distribution trends with peaks near 1 and $2.5 \mu \mathrm{m}$ at a gas temperature of $160.2^{\circ} \mathrm{C}$. In CFB3 (Fig. 6), in the size range of $0.006-0.08 \mu \mathrm{m}, 0.24-0.95 \mu \mathrm{m}$ and 2.44-6.89 $\mu \mathrm{m}$, the mass percentage of OC1 was higher than that of OC2, OC3 and OC4, and this trend was inconsistent with those in CFB4. In CFB1 equipped with bag dust cleaning (Fig.6), mass percent of OC2 were higher than those of OC1, the temperature in the CFB1 flue gas was approximately $74^{\circ} \mathrm{C}$. The results may indicate that the particle filtration device and temperature could affect the mass distribution of carbonaceous fraction $(O C 1, O C 2, O C 3, O C 4)$ in different sizes.

Fig. 6 also shows the mass percentage of EC fractions for the four CFB units. The mass percentage of EC1-3 varied widely at various particle sizes. In all samples, the mass percentage of EC1 was high in different particulate sizes, followed by EC2 and EC3. EC1 was the dominant among 
EC fractions in CFBs. The EC1 emitted may be related to the exhaust humidity and temperature. In CFBs, the maximum mass of EC1 obtained in CFB1 (0.42\% in PM0.95-1.52), CFB2 (0.5\% in PM2.44-4.10), CFB3 (1.33\% in PM0.13-0.24), and CFB4 (0.37\% in PM0.37-0.61) samples were comparable. The mass percentages of EC2 in the CFBs were lower than those of EC1, and similar size distributions were observed from the mass percentages of EC1 and EC2 in the four CFBs. The mass percentage of EC3 was equal to zero. Among the boilers, emissions of EC1 from CFB3 were the highest. The temperature in the CFB3 flue-gas was approximately $50^{\circ} \mathrm{C}$, which was lower than that in other CFBs. Simultaneously, the humidity from the flue gas of CFB3 reached $11 \%$ and was the highest level in all CFBs, potentially causing additional EC1 emissions.

\subsection{Comparison of OC/EC Ratios among Various Boilers and Particle Sizes}

The OC/EC ratio is an important factor for determining source characteristics (Cao et al., 2009). The observed correlations of OC with EC for their mass percentages in the four CFB units are plotted to show an overview of the relationships in Fig. 7. A good correlation was shown between the $\mathrm{OC}$ and $\mathrm{EC}$ in different size fractions for the four CFBs. The higher correlation coefficients were computed for CFB3 (0.699) and CFB4 (0.625). The different correlations manifested that the influence factor for $\mathrm{OC}$ emissions was differ from that of $\mathrm{EC}$, suggesting the relative contribution of $\mathrm{OC}$ and $\mathrm{EC}$ to the composition of PM for CFB units under different working conditions. In addition, slopes between OC and EC were estimated as 0.511 and 0.482 for CFB1 and CFB2, respectively. It is noted that the correlation of $O C$ and $E C$ was commonly prominent in the four CFB units. In Table 2, the OC/EC from fuel gases with different particle sizes from the four CFBs is listed. It was found that the OC/EC in different particle size varied significantly. It may have been caused by the dust-cleaning method and efficiency. At the same particle size fraction, it was observed that the ratio of OC to EC showed important differences because OC powerfully rely on air pollution control devices and coal property (Wierzbicka et al., 2005). So air pollution control devices could influence the PSD of OC and EC, and transform the OC/EC ratios in the flue gas.

\section{CONCLUSION}

Based on this work, the particulate matter with the mass percentage and size-classification particles emitted from four boilers of the same types were collected and characterised. Measurements in the stacks were obtained for an ELPI with a stage dilution sampling system.

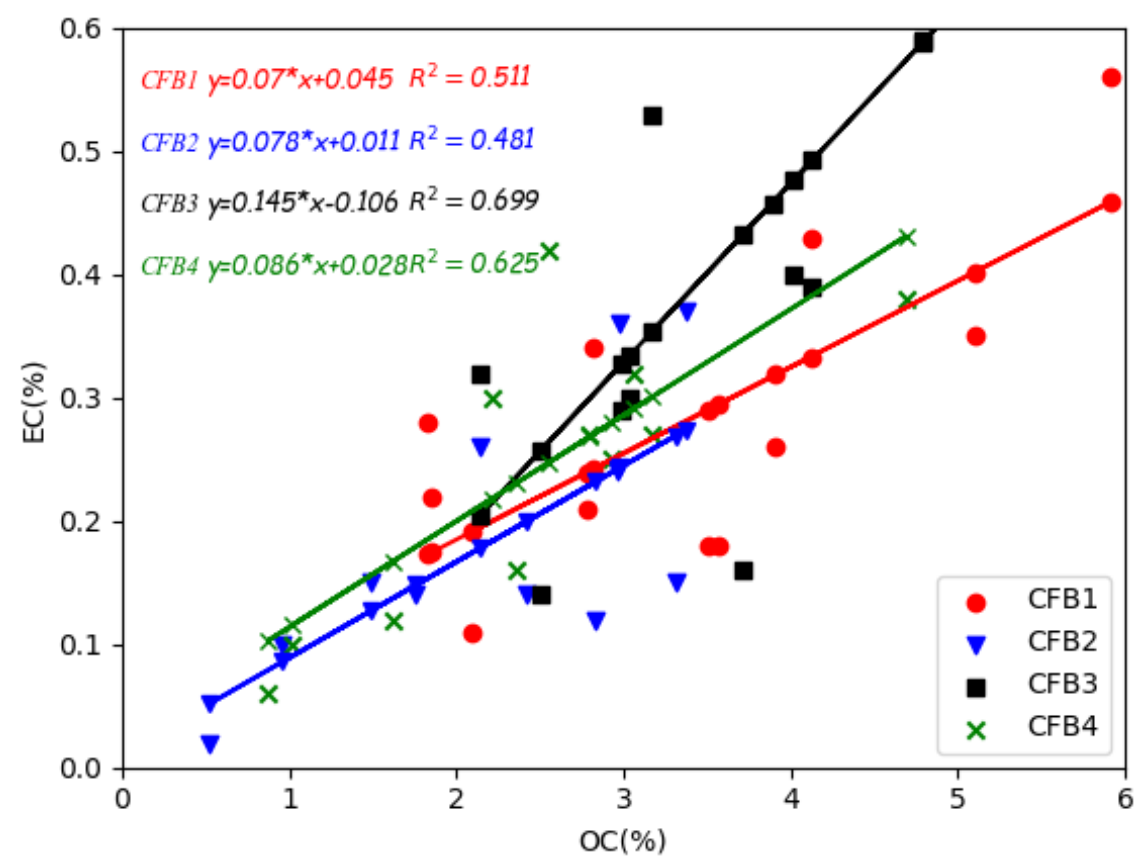

Fig. 7. Correlation between $\mathrm{OC}$ and EC in the four CFBs. 
Table 2. OC/EC ratio in different particle-size bins in the four CFB boilers.

\begin{tabular}{lllll}
\hline Particle size & CFB1 & CFB2 & CFB3 & CFB4 \\
\hline $0.006-0.08$ & 15.04 & 12.57 & 10.05 & 13.50 \\
$0.08-0.13$ & 14.57 & 8.28 & 8.12 & 10.20 \\
$0.13-0.24$ & 10.55 & 8.23 & 7.43 & 7.37 \\
$0.24-0.37$ & 19.83 & 23.58 & 23.19 & 10.33 \\
$0.37-0.61$ & 19.50 & 9.60 & 4.92 & 12.34 \\
$0.61-0.95$ & 19.00 & 9.11 & 5.98 & 14.75 \\
$0.95-1.52$ & 9.58 & 26.00 & 10.59 & 14.50 \\
$1.52-2.44$ & 13.24 & 17.29 & 6.69 & 11.74 \\
$2.44-4.10$ & 8.29 & 22.07 & 10.13 & 9.56 \\
$4.10-6.89$ & 8.41 & 12.33 & 10.31 & 6.07 \\
$6.89-10.23$ & 6.54 & 9.93 & 17.86 & 11.72 \\
\hline
\end{tabular}

It was noted that $\mathrm{Ca}, \mathrm{Fe}, \mathrm{Na}, \mathrm{S}, \mathrm{SO}_{4}{ }^{2-}, \mathrm{Na}^{+}, \mathrm{Ca}^{2+}, \mathrm{NH}_{4}{ }^{+}$and $\mathrm{OC}$, which mainly concentrated in sizes 0.1-2.5 $\mu \mathrm{m}$ in aerodynamic diameter, appeared at relatively high levels in PM from flue gas; The mass distributions of element in different sizes in CFBs after ESP displayed a bimodal distribution, and the highest level contained a fine mode region. In addition, the content of OC2 and OC3 in PM0.13-0.24 appear single peak, mass percentage of $\mathrm{SO}_{4}{ }^{2-}, \mathrm{NH}_{4}{ }^{+}, \mathrm{Ca}^{2+}, \mathrm{Na}^{+}, \mathrm{OC}, \mathrm{EC}, \mathrm{OC} 1$ and EC3 presented a bimodal distribution, and $\mathrm{Cl}^{-}, \mathrm{NO}_{3}{ }^{-}, \mathrm{OC} 4, \mathrm{EC} 1$ and $\mathrm{EC} 2$ had similar size distributions with trimodal distribution; It demonstrates that air pollution control devices can effectively change PM size distribution and associated main chemical compositions. Our results can better quantify chemical compositions from CFB boiler in China. Also, due to the complex conditions and numerous influencing factors of field measurements, chemical compositions of PM based on field tests for real CFB boiler are still limited. Therefore, in order to more accurately assess the relationship between the emissions characteristics and air pollution control devices of CFB boiler on primary air pollutants emissions, a lot of field tests need be conducted.

\section{ABBREVIATIONS}

$\begin{array}{ll}\text { PSD } & \text { particle size distributions } \\ \text { CFB } & \text { circulating fluidized-bed } \\ \text { ELPI } & \text { electrical low-pressure impactor } \\ \text { OC } & \text { organic carbon } \\ \text { EC } & \text { elemental carbon } \\ \text { PECDs } & \text { particulate emission control devices } \\ \text { CFPPs } & \text { coal-fired power plants } \\ \text { FGD } & \text { flue gas desulphurization } \\ \text { T } & \text { temperature } \\ \text { RH } & \text { relative humidity } \\ \text { ESP } & \text { electrostatic precipitators } \\ \text { ESB } & \text { electrostatic bags } \\ \text { SDFGD } & \text { semi-dry flue gas desulphurization } \\ \text { DFGD } & \text { dry flue gas desulphurization } \\ \text { AD } & \text { ammonia desulphurization } \\ \text { SCR } & \text { selective catalytic reduction } \\ \text { SNCR } & \text { selective non-catalytic reduction } \\ \text { APCDs } & \text { air pollution control devices } \\ \text { SO } & \text { sulfur dioxide } \\ \text { NH } & \text { ammonia } \\ \mathrm{NO}_{x} & \text { nitrogen oxides } \\ \text { WESP } & \text { wet electrostatic precipitator } \\ \text { PM } & \text { particulate matter }\end{array}$




\title{
ADDITIONAL INFORMATION
}

\author{
Declaration of Conflicts of Interest \\ The authors declared that they have no conflict of interests
}

\section{ACKNOWLEDGEMENT}

This study is supported by The National Key Research and Development Program of China (2016YFC0208500), and Tianjin Science and Technology Program (18ZXSZSF00160).

\section{REFERENCES}

Álvarez-Ayuso, E., Querol, X., Tomás, A. (2006). Environmental impact of a coal combustiondesulphurization plant: Abatement capacity of desulphurization process and environmental characterization of combustion by-products. Chemosphere 65, 2009-2017. https://doi.org/10. 1016/j.chemosphere.2006.06.070

Arfaoui, J., Boudali, L.K., Ghorbel, A., Delahay, G. (2009). Effect of vanadium on the behaviour of unsulfated and sulfated Ti-pillared clay catalysts in the SCR of $\mathrm{NO}$ by $\mathrm{NH}_{3}$. Catal. Today 142, 234-238. https://doi.org/10.1016/j.cattod.2008.07.032

Bari, M.A., Kindzierski, W.B. (2016.) Fine particulate matter $\left(\mathrm{PM}_{2.5}\right)$ in Edmonton, Canada: source apportionment and potential risk for human health. Environ. Pollut. 218, 219-229. https://doi.org/10.1016/j.envpol.2016.06.014

Cao, J.J., Xu, B.Q., He, J.Q., Liu, X.Q., Han, Y.M., Wang, G.H., Zhu, C.S. (2009). Concentrations, seasonal variations, and transport of carbonaceous aerosols at a remote Mountainous region in western China. Atmos. Environ. 43, 4444-4452. https://doi.org/10.1016/j.atmosenv.2009.06.023

Chow, J.C., Watson, J.G., Crow, D., Lowenthal, D.H., Merrifield, T. (2001). Comparison of IMPROVE and NIOSH carbon measurements. Aerosol Sci. Technol. 34, 23-34. https://doi.org/10.1080/02 786820119073

Cornette, J.F., Coppieters, T., Desagher, D., Annendijck, J., Lepaumier, H., Faniel, N., Dyakov, I., Blondeau, J., Bram, S. (2020). Influence of the dilution system and electrical low pressure impactor performance on particulate emission measurements from a medium-scale biomass boiler. Aerosol Air Qual. Res. 20, 499-519. https://doi.org/10.4209/aaqr.2019.10.0487

Dios, M., Souto, J.A., Casares, J.J. (2013). Experimental development of $\mathrm{CO}_{2}, \mathrm{SO}_{2}$ and $\mathrm{NO}_{x}$ emission factors for mixed lignite and subbituminous coal-fired power plant. Energy 53, 40-51. https://doi.org/10.1016/j.energy.2013.02.043

Duan, J.C., Tan, J.H., Wang, S.L., Chai, F.H., He, K.B., Hao, J.M. (2012). Roadside, urban, and rural comparison of size distribution characteristics of PAHs and carbonaceous components of Beijing, China. J. Atmos. Chem. 69, 337-349. https://doi.org/10.1007/s10874-012-9242-5

Gao, Q., Li, S.Q., Yuan, Y., Zhao, Y.Q., Yao, Q. (2016). Role of minerals in the evolution of fine particulate matter during pulverized coal combustion. Energy Fuels 30, 1011-1021. https://doi.org/10.1021/acs.energyfuels.5b02268

Gao, X.P., Xu, M.H., Yao, H., Han, X., Li, H.H., Sui, J.C., Liu, X.W. (2007). Experimental study on emission characteristics and formation mechanisms of $\mathrm{PM}_{10}$ from a coal-fired boiler. Proc. Chin Soc. Electr. Eng. 17, 11-17 (Chinese). https://doi.org/10.3321/j.issn:0258-8013.2007.17.003

Han, Y.M., Cao, J.J., Lee, S.C., Ho, K.F., An, Z.S. (2010). Different characteristics of char and soot in the atmosphere and their ratio as an indicator for source identification in Xi'an, China. Atmos. Chem. Phys. 10, 59-607. https://doi.org/10.5194/acp-10-595-2010

Huang, Q., Li, S.Q., Li, G.D., Yao, Q. (2017). Mechanisms on the size partitioning of sodium in particulate matter from pulverized coal combustion. Combust. Flame 182, 313-323. https://doi.org/10.1016/j.combustflame.2017.04.026

Hussain, R., Luo, K. (2019). The geological availability and emissions of sulfur and $\mathrm{SO}_{2}$ from the typical coal of China. Aerosol Air Qual. Res. 19, 559-570. https://doi.org/10.4209/aaqr.2018.0 8.0281

Jia, J., Cheng, S.Y., Yao, S., Xu, T. B., Zhang, T.T., Ma, Y.T., Wang, H.L., Duan, W.J. (2018). Emission 
characteristics and chemical components of size-segregated particulate matter in iron and steel industry. Atmos. Environ. 182, 115-127. https://doi.org/10.1016/j.atmosenv.2018.03.051

Lanzerstorfer, C. (2018). Fly ash from coal combustion: Dependence of the concentration of various elements on the particle size. Fuel 228, 263-271. https://doi.org/10.1016/j.fuel.2018. 04.136

Li, J., Zhuang, X.G., Querol, X., Font, O., Moreno, N. (2018). A review on the applications of coal combustion products in China. Int. Geol. Rev. 60, 671-716. https://doi.org/10.1080/00206814. 2017.1309997

Li, J.G., Yang, H.R., Wu, Y.X., Lv, J.F., Yue, G.X. (2013). Effects of the updated national emission regulation in China on circulating fluidized bed boilers and the solutions to meet them. Environ. Sci. Technol. 47, 6681-6687. https://doi.org/10.1021/es4001888

Li, Z., Jiang, J.K., Ma, Z.Z., Fajardo, O. A., Deng, J.G., Duan, L. (2017). Influence of flue gas desulfurization (FGD) installations on emission characteristics of $\mathrm{PM}_{2.5}$ from coal-fired power plants equipped with selective catalytic reduction (SCR). Environ Pollut. 230, 655-662. https://doi.org/10.1016/j.envpol.2017.06.103

Linak, W. P., Miller, C. A., Seames, W. S., Wendt, J.O.L., Ishinomori, T., Endo, Y., Miyamae, S. (2002). On trimodal particle size distributions in fly ash from pulverized-coal combustion. Proc. Combust. Inst. 29, 441-447. https://doi.org/10.1016/S1540-7489(02)80058-X

Ma, X., Wu, J.H., Y Zhang, Y.F., Bi, X.H., Sun, Y.M., Feng, Y.C. (2016). Size-classified variations in carbonaceous aerosols from real coal-fired boilers. Energy Fuels 30, 39-46. https://doi.org/10. 1021/acs.energyfuels.5b01770

Ma, Z.Z., Li, Z., Jiang, J.K., Deng, J.G., Zhao, Y., Wang, S.X., Duan, L. (2017). PM2.5 emission reduction by technical improvement in a typical coal-fired power plant in China. Aerosol Air Qual. Res. 17, 636-643. https://doi.org/10.4209/aaqr.2016.05.0200

Marjamki, M., Keskinen, J., Chen, D.R., Pui, D.Y.H. (2000). Performance evaluation of the electrical low-pressure impactor (ELPI). J. Aerosol. Sci. 31, 249-261. https://doi.org/10.1016/S00218502(99)00052-X

Masiello, C.A. (2004). New directions in black carbon organic geochemistry. Mar. Chem. 92, 201213. https://doi.org/10.1016/j.marchem.2004.06.043

Meij, R., Winkel, B.T. (2004). The emissions and environmental impact of PM10 and trace elements from a modern coal-fired power plant equipped with ESP and wet FGD. Fuel Process. Technol. 85, 641-656. https://doi.org/10.1016/j.fuproc.2003.11.012

Ninomiya, Y., Zhang, L., Sato, A., Dong, Z.B. (2004). Influence of coal particle size on particulate matter emission and its chemical species produced during coal combustion. Fuel Process. Technol. 85, 1065-1088. https://doi.org/10.1016/j.fuproc.2003.10.012

Pan, Y.P., Wang, Y.S., Sun, Y., Tian, S.L., Cheng, M.T. (2013). Size-resolved aerosol trace elements at a rural mountainous site in Northern China: Importance of regional transport. Sci. Total Environ. 461-462, 761-771. https://doi.org/10.1016/j.scitotenv.2013.04.065

Peng, X.L., Hao, Q.J., Wen, T.X., Ji, D.S., Liu, Z.R., Wang, Y.S., He, X.H., Li, X.X., Jiang, C.S. (2018). Characteristics of organic carbon and elemental carbon in atmospheric aerosols in the urban area in Beibei, a suburb of Chongqing. Aerosol Air Qual. Res. 18, 2764-2774. https://doi.org/1 0.4209/aaqr.2017.11.0450

Racherla, P.N., Adams, P.J. (2006). Sensitivity of global tropospheric ozone and fine particulate matter concentrations to climate change. J. Geophys. Res. 111, D24103. https://doi.org/10.102 9/2005JD006939

Ramachandran, B., Herman, R.G., Choi, S., Stenger, H.G., Lyman, C.E., Sale, J.W. (2000). Testing zeolite SCR catalysts under protocol conditions for $\mathrm{NO}_{\mathrm{x}}$ abatement from stationary emission sources. Catal. Today 55, 281-290. https://doi.org/10.1016/S0920-5861(99)00252-7

Saarnio, K., Frey, A., Niemi, J. V., Timonen, H., Ronkko, T., Karjalainen, P., Vestenius, M., Teinilä, K., Pirjola, L., Niemelä, V., Keskinen, J., Häyrinen, A., Hillamo, R. (2014). Chemical composition and size of particles in emissions of a coal-fired power plant with flue gas desulfurization. J. Aerosol Sci. 73, 14-26. https://doi.org/10.1016/j.jaerosci.2014.03.004

Saud, T., Saxena, M., Singh, D.P., Dahiya, M., Sharma, S.K., Datta, A., Gadi, R., Mandal, T.K. (2013). Spatial variation of chemical constituents from the burning of commonly used biomass fuels in rural areas of the Indo-Gangetic Plain (IGP), India. Atmos. Environ. 71, 158-169. https://doi.org/10.1016/j.atmosenv.2013.01.053 
Senior, C.L., Helble, J.J., Sarofim, A.F. (2000). Emissions of mercury, trace elements, and fine particles from stationary combustion sources. Fuel Process. Technol. 65, 263-288. https://doi.org/10.1016/S0378-3820(00)00082-5

Sereika, T., Buinevičius, K., Puida, E., Pabarčius, D. (2017). NOx removal by $\mathrm{NH}_{3}$ and flammable additives in the selective non-catalytic reduction (SNCR) process. Mechanika 23, 661-666. https://doi.org/10.5755/j01.mech.23.5.16331

Wang, G., Ma, Z.Z., Deng, J.G., Li, Z., Duan, L., Zhang, Q. (2019). Characteristics of particulate matter from four coal-fired power plants with low-low temperature electrostatic precipitator in China. Sci. Total Environ. 662, 455-461. https://doi.org/10.1016/j.scitotenv.2019.01.080

Wang, S.X., Zhao, X.J., Li, X.H., Wei, W., Hao, J.M. (2009). Emission characteristics of fine particles from grate firing boilers. China Environ. Sci. 30: 963-968 (Chinese). https://doi.org/10.3321/j.is sn:0250-3301.2009.04.004

Wierzbicka, A., Lillieblad, L., Pagels, J., Strand, M., Gudmundsson, A., Gharibi, A., Swietlicki, E., Sanati, M., Bohgard, M. (2005). Particle emissions from district heating units operating on three commonly used biofuels. Atmos. Environ. 39, 139-150. https://doi.org/10.1016/j.atmosenv.2 004.09.027

Wu, B.B., Tian, H.Z., Hao, Y., Liu, S.H., Liu, X.Y., Liu, W., Bai, X.X., Liang, W.Z., Lin, S.M., Wu, Y.M., Shao, P.Y., Liu, H.J., Zhu, C.Y. (2018). Effects of wet flue gas desulfurization and wet electrostatic precipitators on emission characteristics of particulate matter and its ionic compositions from four 300 MW level ultralow coal-fired power plants. Environ. Sci. Technol. 52, 14015-14026. https://doi.org/10.1021/acs.est.8b03656

Xu, Y., Hu, J.L., Ying, Q., Hao, H.B., Wang, D.X., Zhang, H.L. (2017). Current and future emissions of primary pollutants from coal-fired power plants in Shaanxi, China. Sci. Total Environ. 595, 505-514. https://doi.org/10.1016/j.scitotenv.2017.03.267

Yang, L.X., Wang, D.C., Cheng, S.H., Wang, Z., Zhou, Y., Zhou, X.H. (2007). Influence of meteorological conditions and particulate matter on visual range impairment in Jinan, China. Sci. Total Environ. 383, 164-173. https://doi.org/10.1016/j.scitotenv.2007.04.042

Yi, H.H., Hao, J.M., Duan, L., Tang, X.L., Ning, P., Li, X.H. (2008). Fine particle and trace element emissions from an anthracite coal-fired power plant equipped with a bag-house in China. Fuel 87, 2050-2057. https://doi.org/10.1016/j.fuel.2007.10.009

Yoo, J.I., Seo, Y.C., Shinagawa, T. (2005). Particle-size distributions and heavy metal partitioning in emission gas from different coal-fired power plants. Environ. Eng. Sci. 22, 272-279. https://doi.org/10.1089/ees.2005.22.272

Yue, T., Wang, K., Wang, C.L., Tong, Y.L., Gao, J.J., Zhang, X.X., Zuo, P.L., Tong, L., Liang, Q.M. (2020). Emission characteristics of hazardous atmospheric pollutants from ultra-low emission coalfired industrial boilers in China. Aerosol Air Qual. Res. 20, 877-888. https://doi.org/10.4209/a aqr.2019.10.0531

Zhang, F.Y., Xu, J., Wang, L., Lu, J.M., Li, Y.H., Ni, Y., Wang, W.Y., Krafft, T. (2016). Air quality, patterns and otolaryngology health effects of air pollutants in Beijing in 2013. Aerosol Air Qual. Res. 16, 1464-1472. https://doi.org/10.4209/aaqr.2015.05.0297

Zhang, H.F., Wang, S.X., Hao, J.M., Wan, L., Jiang, J.K., Zhang, M., Mestl, H.E.S., Alnes, L.W.H., Aunan, K., Mellouki, A.W. (2012). Chemical and size characterization of particles emitted from the burning of coal and wood in rural households in Guizhou, China. Atmos. Environ. 51, 9499. https://doi.org/10.1016/j.atmosenv.2012.01.042 